\title{
Overwintering of the western flower thrips in outdoor strawberry crops
}

\author{
Clare Sampson $^{1,3} \cdot$ Jude Bennison ${ }^{2} \cdot$ William D. J. Kirk ${ }^{1}[$
}

Received: 14 May 2019 / Revised: 19 August 2019 / Accepted: 26 September 2019 / Published online: 4 October 2019

(c) The Author(s) 2019

\begin{abstract}
The western flower thrips, Frankliniella occidentalis (Pergande) (Thysanoptera: Thripidae), is a major pest of semi-protected strawberry crops in the UK. These crops are grown outdoors but sheltered by clear polythene tunnels during the growing season from about April to October. The aims of the study were (1) to test whether $F$. occidentalis overwinters in strawberry crops in central England, where overwintering in outdoor crops has not previously been demonstrated and (2) to test whether overwintering affects the thrips population during the following season. F. occidentalis was found breeding on several crop weeds that often flower throughout the year, including common chickweed (Stellaria media), groundsel (Senecio vulgaris) and dandelion (Taraxacum officinale). F. occidentalis female adults were found throughout the winter in flowers of these weeds and caught every month on blue sticky traps. Transparent emergence traps placed over various locations in a secondyear crop in March caught adult thrips over the following month, showing that thrips survived within the crop. Second-year strawberry crops had earlier infestations and significantly more $F$. occidentalis adults per flower than nearby first-year crops at the start of the season, indicating that thrips that overwinter in and around retained crops contribute to pest build-up in the following season. Control of overwintering $F$. occidentalis after the end of first-year cropping before second-year cropping, or growing crops for only 1 year, is a potential strategy to improve thrips management in strawberry. The survival of $F$. occidentalis over winter on outdoor crops raises concerns that the species could in time become established on other outdoor crops.
\end{abstract}

Keywords Frankliniella occidentalis $\cdot$ Thrips major $\cdot$ Mortality $\cdot$ Integrated pest management

\section{Key message}

Communicated by Y. Gao.

Special Issue on novel management tactics for the Western Flower Thrips.

William D. J. Kirk

w.d.j.kirk@keele.ac.uk

Clare Sampson

Clare@ russellipm.com

Jude Bennison

Jude.Bennison@adas.co.uk

1 Centre for Applied Entomology and Parasitology,

School of Life Sciences, Keele University,

Keele, Staffordshire ST5 5BG, UK

2 ADAS Boxworth, Boxworth, Cambridge CB23 4NN, UK

3 Present Address: Russell IPM Ltd, 45 First Avenue, Deeside Industrial Park, Deeside, Flintshire CH5 2NU, UK
- Female adults of western flower thrips can survive the winter in outdoor strawberry crops in central England.

- Control of western flower thrips after the end of first-year cropping before second-year cropping, or growing crops for only 1 year, is a potential strategy to improve management in strawberry.

- The survival of western flower thrips over winter on outdoor crops raises concerns that the species could in time become established outdoors on other crops and elsewhere in northern Europe, particularly if winters become milder with climate change. 


\section{Introduction}

The western flower thrips, Frankliniella occidentalis (Pergande) (Thysanoptera: Thripidae), has become a major pest of semi-protected strawberry crops (Fragaria $\times$ ananassa Duchesne) in the UK. These crops are grown outdoors but are protected by open-sided 'Spanish' polythene tunnels through the growing season from about April to October. The warmer conditions in the tunnel favour thrips development. Everbearer strawberry crops, which have a long flowering and fruiting season, are commonly grown in this way, and their long season also favours the build-up of thrips numbers. Strawberry crops are sometimes grown for 2 years in the UK, although everbearer crops are now more commonly grown for only 1 year to avoid the greater risk of $F$. occidentalis damage. If grown in field soil, the plants are then removed and the field is often ploughed and new beds formed and mulched with black polythene over winter before a new crop is planted the following spring. Field-grown crops are grown on the ground in raised beds or grow bags, but an increasing number of growers grow their crops on table tops, for ease of picking. The pest has developed severe resistance to the chemical insecticides available to growers (Espinosa et al. 2005; Bennison and Fitzgerald 2008; Gao et al. 2012; Sparks et al. 2012). The annual loss of UK strawberry crops to $F$. occidentalis has been as high as $10-20 \%$, with some growers experiencing complete crop loss, but this has improved in recent years with better understanding of integrated pest management practices (Sampson 2014, 2018). In the UK, control of thrips usually relies on integration of the predatory mite Neoseiulus cucumeris Oudemans, predatory bugs Orius species and the predatory mite Stratiolaelaps scimitus with compatible spray treatments, but control can still break down when there are large numbers of adult thrips or incompatible spray treatments are used (Sampson 2014, 2018; Sampson and Kirk 2016). Observations that thrips are more of a problem in fields with a history of the pest or where plants are retained from 1 year to the next suggest that overwintering can contribute to outbreaks (Bennison and Fitzgerald 2008; Sampson 2014, 2018).

$F$. occidentalis overwinters outside in the southern USA and southern Europe but not in the cooler climates of parts of Canada and Denmark (Chambers and Sites 1989; Broadbent and Hunt 1991; Brødsgaard 1993; Pearsall 2002; Kirk and Terry 2003; Krumov and Karadjova 2012). The supercooling point of adults and larvae varies from -13 to $-26{ }^{\circ} \mathrm{C}$ (McDonald et al. 1997b; Tsumuki et al. 2007), but non-freezing mortality occurs at less extreme temperatures and this varies with factors such as photoperiod and cold hardening (Katayama 1997; McDonald et al. $1997 b, c)$. The temperature threshold for development is
8-10 ${ }^{\circ} \mathrm{C}$ (Katayama 1997; McDonald et al. 1998), well above the temperature for mortality. Cold spells at other times of the year, not just in winter, can affect population abundance of insects (Gu et al. 2018), but this has not been studied in thrips. In intermediate climates in northern Europe, such as in the UK, F. occidentalis has predominated in glasshouses and polythene tunnels growing all-year-round crops, such as hardy ornamental nursery stock, where it can breed throughout the year when conditions are suitable, because there is no obligate diapause (Brødsgaard 1994; Ishida et al. 2003). For many years after the arrival of the species in the UK in 1986, it was considered to be only a pest in glasshouses and not to survive outdoors over winter (Baker et al. 1993; Kirk 1996; McDonald et al. 1997a). It does not overwinter in the open as an adult in Slovenia (Trdan et al. 2003) or Bulgaria (Krumov and Karadjova 2012), and possibly not usually in Hungary, although this is uncertain (Jenser 1990; Orosz et al. 2009). The current extent of winter survival outdoors in the UK is unclear and needs to be known in order to devise appropriate pest management strategies for susceptible outdoor crops. Previous research in central England, where our study took place, indicated that $F$. occidentalis would not survive and reproduce after an entire winter outdoors, but predicted that it could survive mild winters in sheltered microhabitats (McDonald et al. 1997b). Survival has been recorded over a mild winter in southern England (Bennison and Fitzgerald 2008). Climate change has led to warmer land temperatures and fewer days of ground frost in the UK over recent decades (Kendon et al. 2018), so the likelihood of winter survival of $F$. occidentalis is slowly increasing.

Most records of overwintering are of adults (Chambers and Sites 1989; Chamberlin et al. 1992), which are more cold hardy than pupae and larvae (Brødsgaard 1993; McDonald et al. 1997b). Typically, all stages of $F$. occidentalis survive for less than a week at constant temperatures below $0{ }^{\circ} \mathrm{C}$, although adults overwintered successfully in the north-eastern USA in the soil and in the open air after 35 consecutive nights below $0{ }^{\circ} \mathrm{C}$, suggesting that warmer temperatures by day may allow some recovery (Felland et al. 1993; McDonald et al. 1997b). Thus, there is uncertainty about the extent to which $F$. occidentalis can overwinter outdoors in the UK and the effect this could have on crop damage.

One potential source of crop infestation is from thrips overwintering on or near the crop. F. occidentalis adults have been recorded on over 100 species of flowering weed species in the USA and Japan (Chamberlin et al. 1992; Chellemi et al. 1994; Cho et al. 1995; Kahn et al. 2005; Katayama 2006), and Kahn et al. (2005) confirmed many species of weed as host plants by rearing larvae to adults for identification. Weeds provide overwintering sites that can bridge the gap between crops (Cho et al. 1995). The importance of 
weeds or retained strawberry plants for overwintering in UK strawberry crops is unknown. Thrips may also overwinter within the crop in the sheltered microclimate provided by plastic and straw mulches.

The aims of this study were to test whether $F$. occidentalis overwinters in and around strawberry crops in central England and to test whether this affects thrips population development during the following season. We also tested for evidence that winters have become milder since the arrival of $F$. occidentalis in England. The main study was carried out from 2008 to 2012 in response to concerns of growers at that time.

\section{Materials and methods}

\section{Overwintering of $F$. occidentalis on strawberry plants and weeds}

Flowers of strawberry and three weed species were sampled monthly from October 2011 (after the end of cropping) to March 2012 (before the first new flowers in the crop), in each of three commercial strawberry fields that had been infested with $F$. occidentalis the previous year. The fields were near Tamworth, Staffordshire and 0.5-1 km apart (grid reference: $52.62^{\circ} \mathrm{N} 1.75^{\circ} \mathrm{W}$ ). The selected weed species can flower through the winter (Clapham et al. 1987), except in very cold years, and are known overwintering sites in the USA (Chamberlin et al. 1992): Stellaria media (L.) Vill. (common chickweed), Senecio vulgaris L. (groundsel) and Taraxacum officinale agg. (dandelion). Samples consisted of five strawberry flowers, three $T$. officinale flowers, ten $S$. vulgaris flowers and ten $S$. media flowers. Where no open flowers were present, senescent or dead flowers were sampled. If no flowers were present, then an equivalent volume of leaves was collected.

Samples were collected more than $20 \mathrm{~m}$ from the edge of the field, to avoid incidental thrips from the hedgerows, and placed directly in $70 \%$ alcohol. The numbers of F. occidentalis adults, other thripid (i.e. in the family Thripidae) adults and larvae were counted under a stereo microscope. F. occidentalis adults were distinguished by the presence of eight antennal segments, uninterrupted wing-vein setae and a pair of long post-ocular setae (Mound et al. 2018). Second-instar thripid larvae were mounted and examined microscopically to verify that $F$. occidentalis was present. Identification keys for the relevant species are only available for second-instar larvae (Vierbergen et al. 2010).

Sticky traps were used to determine whether F. occidentalis was active (flying) during the winter. Two blue sticky traps $(10 \mathrm{~cm} \times 25 \mathrm{~cm}$, Russell IPM Ltd, Deeside, UK) were set up in each of the above three fields on 29 October 2011. Traps were placed vertically (south facing, landscape orientation) on metal posts (height $60 \mathrm{~cm}$ ) with the bottom edge of the traps about $10 \mathrm{~cm}$ above the crop. Pheromone lures (Thripline ${ }_{a m s}$, Syngenta Bioline Ltd, UK), which attract both females and males (Hamilton et al. 2005), were attached. Traps were at least $20 \mathrm{~m}$ apart within a field. Traps and lures were replaced every month. All thrips on the traps were examined under a stereo microscope and the numbers of female and male $F$. occidentalis were counted, respectively.

A temperature data logger (EL-USB-1, Lascar Electronics, Salisbury, UK) was placed in a white delta trap to shade it from the sun at the height of senescent strawberry flowers, about $50 \mathrm{~mm}$ above the strawberry beds.

\section{Overwintering of $F$. occidentalis within the crop and substrate}

The emergence of adult thrips was monitored in early spring in a second-year commercial everbearer strawberry crop (cultivar Evie 2) at Kings Caple, Herefordshire (grid reference: $51.95^{\circ} \mathrm{N} 2.65^{\circ} \mathrm{W}$ ). The crop was grown in rows of raised soil beds, covered with black polythene mulch, at a density of five plants per square metre of tunnel, and had been infested with $F$. occidentalis in the previous year. The soil in the alleys between the rows of raised beds was mulched with loose straw to a variable depth of 2-10 cm. On 19 March 2008, thrips emergence traps were set up in five types of location, replicated at ten positions in the field. The five locations were (1) over an overwintered plant; (2) over the soil in the planting hole after removing the plant; (3) over plant debris on the polythene mulch covering the bed, under the overhanging foliage of a plant; (4) over the straw in the alley between beds; and (5) over the soil under the straw, after removing a section of straw.

Each trap consisted of an upside-down transparent-plastic strawberry punnet $(16 \times 12 \mathrm{~cm}$, without holes in the base $)$ secured firmly to the ground with a strong wire placed over the punnet and pushed into the ground on both sides. A yellow sticky trap was stuck onto the inside of the base of the punnet to catch any emerged thrips. Thrips on the traps were counted at fortnightly intervals on 3 April, 17 April and 1 May 2008. After the final assessment, the thrips were identified to species.

Temperatures were recorded every hour over winter with data loggers (TinyTalk, Gemini Data Loggers, Chichester, UK) in two replicate sections of bed, $1 \mathrm{~m}$ apart, in the following locations: (1) in the planting hole, under the shelter of the overwintering strawberry plant; (2) underneath the polythene mulch covering the bed, $5 \mathrm{~cm}$ from the edge of the planting hole; and (3) underneath the straw in the alley adjacent to the bed. The data loggers were buried so that the sensors were $3 \mathrm{~mm}$ below the soil surface. To avoid pseudo-replication, the mean and SE of temperatures for 
each location type were calculated from the means from the two sensors $(n=2)$, not from all the measurement values. The soil temperatures were compared with standard air temperatures, measured $6 \mathrm{~km}$ away at the weather station in Ross-on-Wye $\left(51.91^{\circ} \mathrm{N} 2.58^{\circ} \mathrm{W}\right)$. The records were downloaded from the UK Met Office (www.metoffice.gov. uk/public/weather/climatehistoric).

\section{Abundance of $F$. occidentalis in first-year and second-year crops}

The adult density of $F$. occidentalis in strawberry flowers in spring was compared between first-year and second-year crops to test whether thrips overwintering within and immediately around the area of the crop between the first and second year contributed to the build-up of the population in second-year crops. The crops were surrounded by a mix of first- and second-year crops, so the invasion pressure from surrounding crops and weeds was similar for both types of crops. Strawberry flowers were sampled approximately monthly, from mid-April (about 2 weeks after first flowering and after the tunnels were covered with polythene) to mid-June 2012, in three matched pairs of first-year and second-year crops near Tamworth, Staffordshire: pair 1 grid references $52.62^{\circ} \mathrm{N} 1.75^{\circ} \mathrm{W}$ and $52.63^{\circ} \mathrm{N} 1.77^{\circ} \mathrm{W}$ (cultivar Driscoll Camarillo); pair 2 grid references $52.63^{\circ} \mathrm{N} 1.77^{\circ} \mathrm{W}$ and $52.63^{\circ} \mathrm{N} 1.78^{\circ} \mathrm{W}$ (cultivar Finesse); and pair 3 grid references $52.72^{\circ} \mathrm{N} 2.27^{\circ} \mathrm{W}$ and $52.73^{\circ} \mathrm{N} 2.27^{\circ} \mathrm{W}$ (cultivar Driscoll Camarillo). Each pair was of the same cultivar and on the same farm, so that cultural methods and the time that flowering started were the same. Crops within pairs were either adjacent or within $250 \mathrm{~m}$ of each other at the closest point. All crops were grown in raised beds, covered in black polythene mulch, at a density of five plants per square metre of tunnel. Each grower used their usual pest control methods, which included releases of the predatory mite $N$. cucumeris and applications of the insecticide spinosad (Tracer) if required. The first-year crops were planted in late February/early March in fields where strawberry crops had been grown the previous year. The field for each crop was notionally divided into 100 equal-sized plots $(10 \times 10)$ and then 8-32 of these, distributed regularly over each field, were selected for sampling. On each sample date, 10-40 flowers were picked per plot and placed in $70 \%$ alcohol. Sample size and number were the same for each pair of fields on each occasion. Medium-aged flowers (petals open, anthers starting to dehisce) were selected from the top of plants, in order to get a consistent sample (Sampson and Kirk 2012). The adult numbers of $F$. occidentalis in each sample were counted under a stereo microscope (identified by colouration, eight antennal segments and uninterrupted wing-vein setae) and mean numbers per flower were compared between first- and second-year crops for each pair of fields each month from April to June. Sub-samples of all the thrips in the flowers were identified under a compound microscope to confirm the identification and identify other species present.

\section{Winter weather trends}

Meteorological records for air temperature at the Keele University weather station, Keele, Staffordshire (grid reference $53.00^{\circ} \mathrm{N} 2.27^{\circ} \mathrm{W}$ ) were analysed for daily minimum temperatures each January, from January 1987 to January 2018 in order to test the hypothesis that winters had become milder since the arrival of $F$. occidentalis in England in mid-1986 (Baker et al. 1993). The same analysis was carried out for the air temperature records at Ross-on-Wye, Herefordshire (see above). Regional weather data for the Midlands region of England was downloaded from the Met Office (www.metof fice.gov.uk/climate/uk/summaries/datasets). The Midlands region, as used by the Met Office, is an approximately triangular area with Bristol, London and Lancaster at the corners. It includes the counties of Herefordshire and Staffordshire.

\section{Statistical analysis}

Data for thrips numbers were compared between the firstyear and the second-year crops within sites with the Wilcoxon-Mann-Whitney test and between crop years across sites with ANOVA. For ANOVA, mean thrips per flower was transformed to $\log _{10}(x+1)$ to homogenise the variance. Residuals were checked for normality using an Anderson-Darling test. Statistical analysis was carried out with Minitab 18 (Minitab Inc., USA) for ANOVA and R v3.5.3 (R Core Team 2019) for Wilcoxon-Mann-Whitney tests. Tables and figures show the means $( \pm \mathrm{SE})$ of untransformed data. The time series for temperatures showed no periodicity or autocorrelation and so were analysed by linear regression with Minitab 18.

\section{Results}

\section{Overwintering of $F$. occidentalis on strawberry plants and weeds}

Female adults of $F$. occidentalis were present throughout the winter in senescent or dead strawberry flowers or flowers of weeds within the cropping area in Staffordshire (Table 1). Male adults and larvae of $F$. occidentalis were found in flowers in November and December of 2011, but not in January, February or March of 2012 (Table 1).

Low numbers of $F$. occidentalis adults were also caught on blue sticky pheromone traps throughout the winter. Females were caught from November in 2011 to March in 
Table 1 Monthly surveys of $F$. occidentalis adults and thripid larvae in a strawberry crop in Staffordshire during winter 2011-2012

\begin{tabular}{llllll}
\hline Source & \multicolumn{4}{l}{ Winter months $2011-2012$} & \\
\cline { 2 - 5 } & November & December & January & February & March \\
\hline Strawberry & $3 / 2(6)$ & $2 / 0(4)$ & $1 / 0(0)^{*}$ & $0 / 0(0)^{*}$ & $2 / 0(0)^{*}$ \\
Senecio vulgaris & $1 / 1(11)$ & $1 / 0(2)$ & $1 / 0(0)$ & $0 / 0(0)$ & $1 / 0(0)$ \\
Taraxacum officinale & $9 / 4(2)$ & $3 / 1(2)$ & $1 / 0(0)$ & $1 / 0(0)$ & $0 / 0(0)$ \\
Stellaria media & $1 / 0(2)$ & $1 / 1(0)$ & $0 / 0(0)^{*}$ & $0 / 0(0)^{*}$ & $3 / 0(0)$ \\
Trap catch (females) & $4 \pm 2$ & $0.3 \pm 0.2$ & $0.2 \pm 0.2$ & $0.2 \pm 0.2$ & $14 \pm 7$ \\
Trap catch (males) & $2 \pm 1$ & $0.2 \pm 0.2$ & $0 \pm 0$ & $0 \pm 0$ & $0 \pm 0$ \\
\hline
\end{tabular}

The total numbers in the samples $(n=3)$ are given in the order: adult females/adult males (larvae). Over $90 \%$ of the larvae from the samples of thripid larvae were F. occidentalis. Samples were of flowers, if present, but otherwise of leaves (indicated by an asterisk). Trap catches are the monthly mean per trap ( \pm SE) from blue pheromone sticky traps $(n=6)$

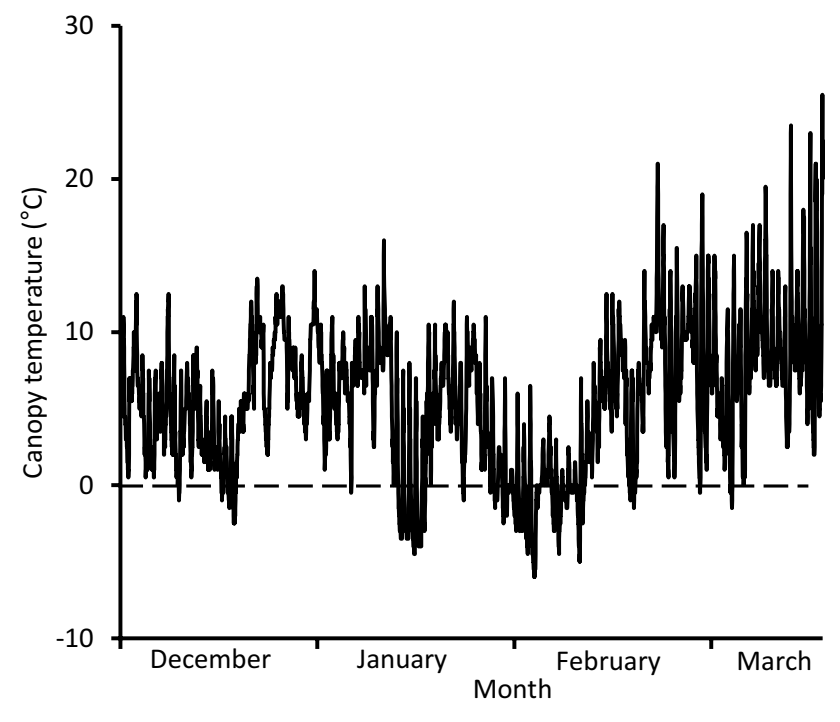

Fig. 1 Air temperatures in a strawberry crop canopy at the height of senescent flowers (about $50 \mathrm{~mm}$ above the bed) near Tamworth, Staffordshire, central England, recorded every $30 \mathrm{~min}$ from 1 December 2011 to 20 March 2012

2012, whereas males were caught only in November and December of 2011 (Table 1). Very few thrips were caught in January and February 2012, when daily mean temperatures were -2.5 to $12.6^{\circ} \mathrm{C}$ and daily maximum temperatures were 0.5 to $21.0^{\circ} \mathrm{C}$. The temperature only exceeded $15^{\circ} \mathrm{C}$, the threshold for flight (Pearsall 2002; O'Leary 2005), on 4 days. Temperatures fell below $0{ }^{\circ} \mathrm{C}$ on 29 nights, but daytime temperatures always exceeded $0{ }^{\circ} \mathrm{C}$ (Fig. 1). According to Met Office data for the mean daily minimum temperatures in the Midlands region (available at www.metoffice. gov.uk/public/weather/climatehistoric), winter 2012 had the 21 st coldest January and the 10th coldest February over the period of 32 years (1987-2018) since the arrival of F. occidentalis in the UK. For comparison with recent years, 2017 had the 8th coldest January and the 27th coldest February and 2018 had the 24th coldest January and the 3rd coldest February over the same period.

\section{Overwintering of $F$. occidentalis within the crop and substrate}

Adult $F$. occidentalis was caught in the emergence traps at all the trapping locations in the field in Herefordshire (Table 2). A total of 54 adult thrips were caught by the emergence traps and $51(94 \%)$ were $F$. occidentalis. The mean emergence densities ranged from 0.4 to 1.7 thrips per $0.019 \mathrm{~m}^{2}$, which is equivalent to $21-89$ thrips per $\mathrm{m}^{2}$.

Over the preceding winter, January was relatively mild, whereas February was much colder. According to Met Office data for the mean daily minimum temperature in the Midlands region, winter 2008 had the 31 st coldest January and 9th coldest February over the period from 1987 to 2018. The
Table 2 Numbers of adult thrips caught per emergence trap (mean \pm SE) from five locations in an everbearer strawberry crop in Herefordshire from 19 March to 1 May $2008(n=10)$

\begin{tabular}{llllll}
\hline Date range & \multicolumn{4}{l}{ Location of trap } \\
\cline { 2 - 6 } & Over plant & $\begin{array}{l}\text { Over soil in the } \\
\text { planting hole }\end{array}$ & $\begin{array}{l}\text { Over plant } \\
\text { debris on mulch }\end{array}$ & $\begin{array}{l}\text { Over straw } \\
\text { between rows }\end{array}$ & $\begin{array}{l}\text { Over soil } \\
\text { under straw }\end{array}$ \\
\hline 19 March-3 April & $0.5 \pm 0.2$ & $0.5 \pm 0.2$ & $0.2 \pm 0.1$ & $1.2 \pm 0.5$ & $0.6 \pm 0.3$ \\
3-17 April & $0.2 \pm 0.1$ & $0.0 \pm 0.0$ & $0.2 \pm 0.1$ & $0.1 \pm 0.1$ & $0.2 \pm 0.2$ \\
17 April-1 May & $0.6 \pm 0.3$ & $0.4 \pm 0.2$ & $0.0 \pm 0.0$ & $0.4 \pm 0.3$ & $0.3 \pm 0.2$ \\
Total & $1.3 \pm 0.4$ & $0.9 \pm 0.3$ & $0.4 \pm 0.2$ & $1.7 \pm 0.6$ & $1.1 \pm 0.5$ \\
\hline
\end{tabular}

Each trap enclosed an area of $0.019 \mathrm{~m}^{2}$ 
soil temperatures at three sheltered locations within the crop were broadly similar in terms of minimum and maximum (Table 3). In all cases, the mean daily minimum temperature was higher than that of the corresponding air temperature, and the mean daily maximum temperature was lower than that of the corresponding air temperature.

\section{Abundance of $F$. occidentalis in first-year and second-year crops}

There were significantly more adult $F$. occidentalis in the second-year crops than in the first-year crops within all the pairs of first-year and second-year crops in June and May and for two out of three pairs in April 2012 (Table 4).

Table 3 Daily minimum temperatures and daily maximum temperatures in ${ }^{\circ} \mathrm{C}$ (mean $\pm \mathrm{SE}$ ) each month from sensors placed $3 \mathrm{~mm}$ below the soil surface at each of three different locations in an everbearer strawberry crop in Herefordshire in 2008

\begin{tabular}{lll}
\hline Location & \multicolumn{2}{l}{ Month } \\
\cline { 2 - 2 } & January & February \\
\hline In planting hole & & \\
$\quad$ Mean daily min & $4.3 \pm 0.1$ & $2.8 \pm 0.04$ \\
Mean daily max & $7.2 \pm 0.1$ & $7.0 \pm 0.2$ \\
Under black polythene mulch & & \\
Mean daily min & $4.5 \pm 0.1$ & $3.0 \pm 0.1$ \\
Mean daily max & $7.1 \pm 0.01$ & $6.9 \pm 0.1$ \\
Under straw between rows & & \\
Mean daily min & $4.3 \pm 0.4$ & $2.9 \pm 0.4$ \\
Mean daily max & $6.9 \pm 0.3$ & $6.0 \pm 0.3$ \\
Air temperature at weather station & & \\
Mean daily min & 3.9 & 1.0 \\
Mean daily max & 10.3 & 10.0 \\
\hline
\end{tabular}

Locations were replicated twice. There was no significant difference $(P>0.05)$ between the minimum temperatures or between the maximum temperatures in January or February at the three locations within the crop. The air temperatures from the nearby weather station at Ross-on-Wye are given for comparison
In April, no adult $F$. occidentalis was found in the flower samples from first-year crops, but they were found in all the second-year crops (Table 4). Across the three sites, second-year crops had more thrips than first-year crops by a factor of 43 in May and a factor of 27 in June. In May and June, the percentage of flowers occupied by thrips remained low at $0-15 \%$ in all the first-year crops, but was $36-99 \%$ in the second-year crops.

The overall effect was that by June, there were significantly more adults of $F$. occidentalis in second-year crops than in the first-year crops $\left(F_{(1,4)}=10.7, P=0.03\right)$.

The proportion of adult thrips that were $F$. occidentalis was variable at the start of the season but was in the range $37-62 \%$. Most of the other thrips were the rubus thrips (Thrips major Uzel). Other thripids, each present in low numbers and less than $10 \%$ of the population in total, in decreasing order, were $T$. tabaci Lindeman, T. fuscipennis Haliday, F. intonsa (Trybom), T. atratus Haliday, T. angusticeps Uzel, T. vulgatissimus (Haliday) and F. tenuicornis (Uzel).

\section{Winter weather trends}

To test whether winter survival of $F$. occidentalis could be attributed to winters becoming warmer over time in central England, mean daily minimum temperatures in January, which is typically the coldest month, were analysed from January 1987, after the species was first recorded in the UK in mid-1986 (Baker et al. 1993), to January 2018. There was no apparent trend over 32 years at Keele University, Staffordshire, and the regression of mean daily minimum temperature on year was not significant (Fig. 2). The same analysis with Met Office data from Ross-onWye, Herefordshire, was not significant $\left(R_{(30)}^{2}=0.000\right.$, $P=0.97)$.

Table 4 Numbers of adult $F$. occidentalis per flower (mean \pm SE) from plots (10 flowers per plot) across fields in spring 2012 at three sites in Staffordshire

\begin{tabular}{|c|c|c|c|c|c|c|c|c|c|}
\hline \multirow[t]{2}{*}{ Month } & \multicolumn{3}{|l|}{ Site 1} & \multicolumn{3}{|l|}{ Site 2} & \multicolumn{3}{|l|}{ Site 3} \\
\hline & First year & Second year & $P$ & First year & Second year & $P$ & First year & Second year & $P$ \\
\hline April & $0.00 \pm 0.00$ & $0.07 \pm 0.03$ & 0.01 & $0.00 \pm 0.00$ & $0.12 \pm 0.04$ & 0.002 & $0.00 \pm 0.00$ & $0.03 \pm 0.02$ & 0.08 \\
\hline May & $0.11 \pm 0.02$ & $0.56 \pm 0.06$ & $<0.001$ & $0.02 \pm 0.02$ & $6.94 \pm 1.49$ & $<0.001$ & $0.05 \pm 0.02$ & $0.24 \pm 0.07$ & 0.04 \\
\hline June & $0.12 \pm 0.06$ & $1.32 \pm 0.27$ & 0.001 & $0.15 \pm 0.05$ & $7.99 \pm 0.95$ & $<0.001$ & $0.18 \pm 0.08$ & $2.64 \pm 0.67$ & $<0.001$ \\
\hline
\end{tabular}

Each site had a matched pair of the first-year and the second-year crops in adjacent or very close fields. Plots were treated as replicates: site 1 ( $n=10$ plots in April, 32 plots in May and 8 plots in June), site 2 ( $n=10$ plots in April, 8 plots in May and June) and site 3 ( $n=10$ plots each month). $P$ values are for differences in thrips per flower between the first-year and the second-year crops at each site in each month using a Wilcoxon-Mann-Whitney test 


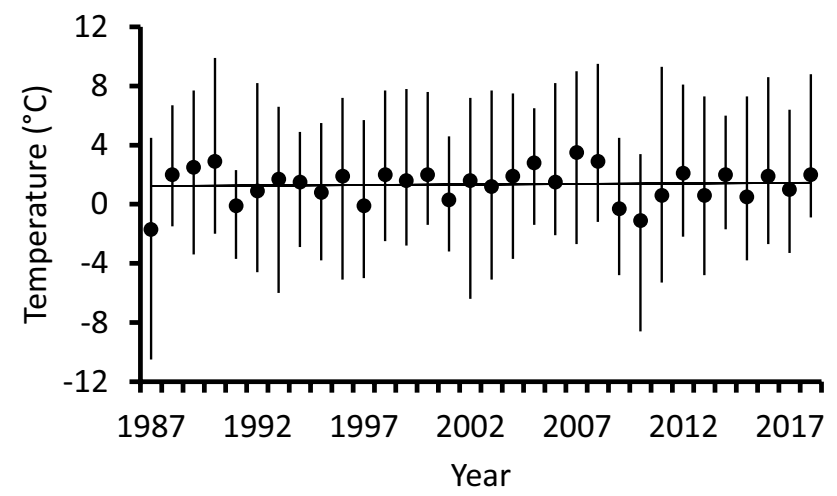

Fig. 2 Minimum air temperatures each January at the weather station at Keele University, Staffordshire, central England, from 1987 (after the arrival of $F$. occidentalis in the UK in mid-1986) through to 2018 $(n=32)$. The symbol indicates the mean daily minimum and the top and bottom of the bar indicate the highest daily minimum and the lowest daily minimum, respectively, for each month. The fitted trend line for the mean daily minimum was not significant $\left(R_{(30)}^{2}=0.004\right.$, $P=0.74)$

\section{Discussion}

Surveys of thrips in flowers and on sticky traps showed that female adults of $F$. occidentalis were active in and around a strawberry crop in central England throughout the winter from November to March (Table 1). A few adults were caught on pheromone sticky traps from January to March, even though the air temperature in the crop canopy rarely reached the flight threshold of $15^{\circ} \mathrm{C}$ (Pearsall 2002; O'Leary 2005). Male adults apparently died out over winter; they are known to be much shorter lived than females in cold conditions (Tsumuki et al. 2007). No larvae were found from January to March, when mean temperatures were mostly below the development threshold of $8-10{ }^{\circ} \mathrm{C}$ (Katayama 1997; McDonald et al. 1998), which supports the view that adults are the dominant overwintering form (McDonald et al. 1997b). Populations can develop from adult females because thrips are haplodiploid. The presence of larvae on three common crop weeds in November and December confirmed that the weeds were host plants and suggested that they could harbour thrips populations for much of the year and be a source of thrips for both the first- and second-year crops. The role of these crop weeds needs further study. Weeds could cause an influx of thrips (Allsopp 2010), but they could also be of benefit by supporting predator populations (Honek et al. 2013).

Emergence traps placed over various locations within the strawberry crop showed that many F. occidentalis survived the winter within the crop and emerged from the substrate in March and April. They are likely to have survived the winter as adults rather than as larvae or pupae, because the immature stages are less cold hardy and lack the protection of an obligate diapause (Brødsgaard 1993; McDonald et al. 1997b; Ishida et al. 2003), although some survival as larvae or pupae in the soil cannot be ruled out. The surprisingly high densities of 21-89 thrips per $\mathrm{m}^{2}$ emerging from the substrate at the start of a second-year crop are likely to give a considerable boost to infestation levels. Although first-year crops are sometimes planted in fields that had an infested second-year crop the year before, the ground is typically ploughed to reduce thrips populations before planting again, so similar emergence rates would not be expected in a firstyear crop. This is not possible between the first and second year of a 2-year crop because the crop is in the way.

F. occidentalis has established itself in semi-protected strawberry crops and expanded its range within the UK, where it can no longer be considered to be confined to glasshouse crops. It is not clear whether the survival of $F$. occidentalis outdoors in strawberry crops is the result of a change in the environment or a change in the physiology or behaviour of the thrips since the species arrived the UK in 1986. It could be just the result of the species becoming more widespread and having more opportunities to survive outdoors. The use of polythene tunnels for everbearer crops has favoured $F$. occidentalis by providing a continuity of breeding sites with favourable temperatures. Although climate change could have increased winter survival as winters have become milder (Kendon et al. 2018), the effect was not apparent from mean minimum temperatures in January at a site in Staffordshire (Fig. 2) or a site in Herefordshire, presumably because the annual fluctuations in one place are much larger than the small average changes in climate measured over large areas.

Outdoor soil-grown strawberry crops are commonly mulched with polythene and have straw between the rows, offering many protected microclimates. The reduced range of soil temperatures that we found compared with air temperatures is consistent with the known effects of mulches, which reduce maximum temperatures and increase minimum temperatures (Weil and Brady 2017). The polythene, straw and plant cover appear to provide thrips with some protection from low temperatures by thermal buffering, but it is unclear whether this is any different from that available naturally from low-growing vegetation and fallen leaves.

Comparisons of where overwintering occurs among Europe, the USA and Canada do not appear to give a consistent picture. F. occidentalis can overwinter in parts of British Columbia and the north-eastern USA that has much colder winters than some areas of Europe where it does not overwinter (Felland et al. 1993). This does not appear to be due to a physiological difference between the thrips from different regions (Brødsgaard 1993). Although there could be behavioural differences, the extent of opportunities to move into protected microclimates, the speed of exposure to cold, photoperiod length, whether feeding has occurred 
recently and intermittent periods of favourable temperature could also play a part (McDonald et al. 1997a, c). Despite these many factors, LTime $_{50}$, the time required to kill $50 \%$ of a population at a constant $-5{ }^{\circ} \mathrm{C}$, has proved a good predictor of establishment potential for invasive insects, including thrips, because of its correlation with field survival over winter in the UK (Bale and Walters 2001).

Low-temperature mortality in winter must exert a strong selection pressure for physiological or behavioural adaptations that would increase winter survival. If this were to occur, F. occidentalis could become more difficult to control in strawberry in the UK and could become established on other outdoor crops in the UK and other parts of northern Europe, such as fruit trees (Cossentine et al. 1999). However, since our study in 2012, F. occidentalis has not become more of a problem in early season strawberry in England (R. Irving, pers. comm., 2019). This indicates that we are not seeing a general increase in overwintering by $F$. occidentalis.

More $F$. occidentalis adults per flower were recorded in second-year crops than first-year crops in three otherwisesimilar matched pairs of crops from April to June, which confirms the observations of growers that thrips are more of a problem in second-year crops (Bennison and Fitzgerald 2008; Sampson 2014, 2018). The high rate of emergence of overwintered adults from the substrate in spring suggests the most likely reason. The widespread distribution and abundance of $F$. occidentalis in second-year crops at first flowering in April show that most of the thrips over wintered within the crop. Over the last decade, growers in the UK have increasingly favoured 1-year crops to reduce the thrips pressure they have experienced in second-year crops. The lower numbers of $F$. occidentalis in first-year crops are more easily controlled by the predatory mite $N$. cucumeris.

Several other thrips species were found in strawberry flowers. These are all common, polyphagous, flower-inhabiting species, although $F$. tenuicornis breeds only on grasses and cereals (Mound et al. 2018). T. major, T. tabaci, T. fuscipennis, $T$. atratus and $F$. intonsa are all known to infest strawberry crops and have been associated with damage (Buxton and Easterbrook 1988; Easterbrook 1991; Gremo et al. 1997). Thrips major is one of the commonest thrips species in flowers in the UK and the rest of Europe (Mound et al. 2018) and was present in strawberry flowers in Staffordshire in similar numbers to $F$. occidentalis at the start of the season, presumably because, as a native species, it survives better over winter. These other species have probably been reduced in the past by the insecticide treatments used against $F$. occidentalis and other pests in UK strawberry crops, but they have the potential to return as strawberry pests, particularly if they were to develop insecticide resistance.

Growers can reduce the risk of damage from F. occidentalis by growing 1-year crops, if economically viable, or by reducing overwintering thrips populations, if appropriate treatments become available. Slower-acting or longer-residual biopesticides or chemical pesticides could have a role at the end of cropping, because fruit will not be harvested for many months, so long as they do not interfere with predator establishment the following spring.

\section{Author contributions}

CS, JB and WDJK conceived and designed the research, CS and JB conducted experiments and CS and WDJK analysed the data and wrote the manuscript. All the authors read and approved the manuscript.

Acknowledgements We thank the ADAS field team for carrying out the experiments in Herefordshire and Chris Dyer (ADAS statistician) for analysing the resulting data, and Robert Irving (ADAS soft fruit consultant) for helpful discussions on the recent experience of commercial strawberry growers in the UK. The experiments in Herefordshire were funded by the Horticultural Development Council (Project SF 80). All other field research was co-funded through the Horticulture LINK programme in the UK (Project HL01107) by the Department for Environment, Food and Rural Affairs, together with a consortium of industrial companies (Agriculture and Horticulture Development Board, Bayer CropScience Ltd, Belchim Crop Protection Ltd, Berryworld Ltd, Berry Gardens Growers Ltd, Certis Europe BV, CPM Retail Ltd, East Malling Ltd, KG Growers Ltd, Russell IPM Ltd, Syngenta Bioline Ltd and Tesco Stores Ltd). We thank Mr Simon Clarke, $\mathrm{Mr}$ George Busby and Sons and Mr Neil Cockburn for allowing access to their fields. Traps for experiments in Staffordshire were donated by Russell IPM Ltd and pheromone lures by Syngenta Bioline Ltd.

\section{Compliance with ethical standards}

Conflict of interest The authors declare that they have no conflict of interest. The research funders did not participate in the design or analysis of the experiments.

Ethical approval This article does not involve any human and/or animal participants, and insects are not included in ethical consideration in the UK.

Open Access This article is distributed under the terms of the Creative Commons Attribution 4.0 International License (http://creativeco mmons.org/licenses/by/4.0/), which permits unrestricted use, distribution, and reproduction in any medium, provided you give appropriate credit to the original author(s) and the source, provide a link to the Creative Commons license, and indicate if changes were made.

\section{References}

Allsopp E (2010) Seasonal occurrence of western flower thrips, Frankliniella occidentalis (Pergande), on table grapes in the Hex River Valley, South Africa. S Afr J Enol Vitic 31:49-57

Baker CRB, Barker I, Bartlett PW, Wright DW (1993) Western flower thrips, its introduction and spread in Europe and role as a vector of tomato spotted wilt virus. In: Ebbels D (ed) British crop protection 
council monograph, no. 54. Plant health and the European single market, British Crop Protection Council, Farnham, pp 355-360

Bale JS, Walters KFA (2001) Overwintering biology as a guide to the establishment potential of non-native arthropods in the UK. In: Atkinson D, Thorndyke M (eds) Environment and animal development: genes, life histories and plasticity. BIOS Scientific Publishers, Oxford, pp 343-354

Bennison JA, Fitzgerald J (2008) Getting to grips with thrips. HDC News 143:20-21

Broadbent AB, Hunt DWA (1991) Inability of western flower thrips, Frankliniella occidentalis (Pergande) (Thysanoptera, Thripidae), to overwinter in southern Ontario. Proc Entomol Soc Ont 122:47-49

Brødsgaard HF (1993) Cold hardiness and tolerance to submergence in water in Frankliniella occidentalis (Thysanoptera: Thripidae). Environ Entomol 22:647-653

Brødsgaard HF (1994) Effect of photoperiod on the bionomics of Frankliniella occidentalis (Pergande) (Thysanoptera, Thripidae). J Appl Entomol 117:498-507

Buxton JH, Easterbrook MA (1988) Thrips as a probable cause of severe fruit distortion in late-season strawberries. Plant Pathol 37:278-280

Chamberlin JR, Todd JW, Beshear RJ, Culbreath AK, Demski JW (1992) Overwintering hosts and wingform of thrips, Frankliniella spp., in Georgia (Thysanoptera: Thripidae): implications for management of spotted wilt disease. Environ Entomol 21:121-128

Chambers WS, Sites RW (1989) Overwintering thrips fauna in croplands of the Texas South Plains. Southwest Entomol 14:325-328

Chellemi DO, Funderburk JE, Hall DW (1994) Seasonal abundance of flower-inhabiting Frankliniella species (Thysanoptera: Thripidae) on wild plant species. Environ Entomol 32:337-342

Cho K, Eckel CS, Walgenbach JF, Kennedy GG (1995) Overwintering of thrips (Thysanoptera: Thripidae) in North Carolina. Environ Entomol 24:58-67

Clapham AR, Tutin TG, Moore DM (1987) Flora of the British isles, 3rd edn. Cambridge University Press, Cambridge

Core Team R (2019) A language and environment for statistical computing. R Foundation for Statistical Computing, Vienna

Cossentine JE, Hogue EJ, Jensen LBM (1999) The influence of orchard ground cover and introduced green lacewings on spring populations of western flower thrips in apple orchards. J Entomol Soc B C 96:7-12

Easterbrook MA (1991) Species of thrips associated with flowers of late-flowering strawberries. Entomologist 110:5-10

Espinosa PJ, Contreras J, Quinto V, Gravalos C, Fernandez E, Bielza $P$ (2005) Metabolic mechanisms of insecticide resistance in the western flower thrips, Frankliniella occidentalis (Pergande). Pest Manag Sci 61:1009-1015

Felland CM, Hull LA, Teulon DAJ, Cameron EA (1993) Overwintering of western flower thrips (Thysanoptera: Thripidae) in Pennsylvania. Can Entomol 125:971-973

Gao YL, Lei ZR, Reitz SR (2012) Western flower thrips resistance to insecticides: detection, mechanisms and management strategies. Pest Manag Sci 68:1111-1121

Gremo F, Bogetti C, Scarpelli F (1997) I tripidi dannosi alla fragola. Inf Agrar 53:85-89

Gu SM, Han P, Ye ZP, Perkins LE, Li J, Wang HQ, Zalucki MP, Lu ZZ (2018) Climate change favours a destructive agricultural pest in temperate regions: late spring cold matters. J Pest Sci 91:1191-1198

Hamilton JGC, Hall DR, Kirk WDJ (2005) Identification of a maleproduced aggregation pheromone in the western flower thrips Frankliniella occidentalis. J Chem Ecol 31:1369-1379

Honek A, Stys P, Martinkova Z (2013) Arthropod community of dandelion (Taraxacum officinale) capitula during seed dispersal. Biologia 68:330-336
Ishida H, Murai T, Sonoda S, Yoshida H, Izumi Y, Tsumuki H (2003) Effects of temperature and photoperiod on development and oviposition of Frankliniella occidentalis (Pergande) (Thysanoptera: Thripidae). Appl Entomol Zool 38:65-68

Jenser G (1990) Über das Freiland-Auftreten von Frankliniella occidentalis (Perg.) (Thysanoptera) in Ungarn. Anz Schädlingskd Pflanzenschutz Umweltschutz 63:114-116

Kahn ND, Walgenbach TF, Kennedy GG (2005) Summer weeds as hosts for Frankliniella occidentalis and Frankliniella fusca (Thysanoptera: Thripidae) and as reservoirs for tomato spotted wilt tospovirus in North Carolina. J Econ Entomol 98:1810-1815

Katayama H (1997) Effect of temperature on development and oviposition of western flower thrips Frankliniella occidentalis (Pergande). Jpn J Appl Entomol Zool 41:225-231

Katayama H (2006) Seasonal prevalence of the occurrence of western flower thrips Frankliniella occidentalis (Pergande) (Thysanoptera: Thripidae) on weed hosts growing around ornamental fields. Appl Entomol Zool 41:93-98

Kendon M, McCarthy M, Jevrejeva S, Matthews A, Legg T (2018) State of the UK climate 2017. Int J Climatol 38(Suppl 2):1-35

Kirk WDJ (1996) Thrips. Naturalists' handbooks 25. Richmond Publishing Co. Ltd., Slough, p 70

Kirk WDJ, Terry LI (2003) The spread of the western flower thrips Frankliniella occidentalis (Pergande). Agric For Entomol 5:301-310

Krumov V, Karadjova O (2012) Influence of climate change on the potential for establishment of Frankliniella occidentalis (Thysanoptera: Thripidae) in Bulgaria. Acta Phytopathol Entomol Hung 47:113-116

McDonald JR, Bale JS, Walters KFA (1997a) Effects of sub-lethal cold stress on the western flower thrips, Frankliniella occidentalis. Ann Appl Biol 131:189-195

McDonald JR, Bale JS, Walters KFA (1997b) Low temperature mortality and overwintering of the western flower thrips Frankliniella occidentalis (Thysanoptera: Thripidae). Bull Entomol Res 87:497-505

McDonald JR, Bale JS, Walters KFA (1997c) Rapid cold hardening in the western flower thrips Frankliniella occidentalis. J Insect Physiol 43:759-766

McDonald JR, Bale JS, Walters KFA (1998) Effect of temperature on development of the western flower thrips, Frankliniella occidentalis (Thysanoptera: Thripidae). Eur J Entomol 95:301-306

Mound LA, Collins DW, Hastings A (2018) Thysanoptera Britannica et Hibernica-thrips of the British Isles. Lucidcentral.org, Identic Pty Ltd, Stafford Heights

O'Leary AT (2005) Flight and oviposition in the western flower thrips. Ph.D. thesis, Keele University, UK

Orosz S, Kovacs C, Juhasz M, Toth F (2009) Observations on the overwintering of Frankliniella occidentalis (Pergande) (Thysanoptera: Thripidae) under climatic conditions of Hungary. Acta Phytopathol Entomol Hung 44:267-276

Pearsall IA (2002) Daily flight activity of the western flower thrips (Thysan., Thripidae) in nectarine orchards in British Columbia, Canada. J Appl Entomol 126:293-302

Sampson C (2014) Management of pesticide-resistant western flower thrips on tunnel-grown strawberry: a study of the reasons for successes and failures on commercial production sites. AHDB, Agriculture and Horticulture Development Board (AHDB), Kenilworth, $\mathrm{p} 19$

Sampson C (2018) Sustainable management of the western flower thrips in strawberry crops. Outlooks Pest Manag 29:180-184

Sampson C, Kirk WDJ (2012) Flower stage and position affect population estimates of the western flower thrips, Frankliniella occidentalis (Pergande), in strawberry. Acta Phytopathol Entomol Hung 47:133-140 
Sampson C, Kirk WDJ (2016) Predatory mites double the economic injury level of Frankliniella occidentalis in strawberry. Biocontrol 61:661-669

Sparks TC, Dripps JE, Watson GB, Paroonagian D (2012) Resistance and cross-resistance to the spinosyns - a review and analysis. Pestic Biochem Phys 102:1-10

Trdan S, Bergant K, Jenser G (2003) Monitoring of western flower thrips (Frankliniella occidentalis [Pergande], Thysanoptera) in the vicinity of greenhouses in different climatic conditions in Slovenia. Agricultura 2:1-6

Tsumuki H, Ishida H, Yoshida H, Sonoda S, Izumi Y, Murai T (2007) Cold hardiness of adult western flower thrips, Frankliniella occidentalis (Pergande) (Thysanoptera: Thripidae). Appl Entomol Zool 42:223-229
Vierbergen G, Kucharczyk H, Kirk WDJ (2010) A key to the second instar larvae of the Thripidae of the Western Palaearctic region (Thysanoptera). Tijdschr Entomol 153:99-160

Weil RR, Brady NC (2017) The nature and properties of soils, 15th edn. Pearson Education, Harlow

Publisher's Note Springer Nature remains neutral with regard to jurisdictional claims in published maps and institutional affiliations. 